\title{
Impact of habitat manipulation on the diversity and abundance of beneficial and pest arthropods in sugarcane ratoon
}

\author{
HERI PRABOWO ${ }^{1,2}$, BAMBANG TRI RAHARDJO $^{1, \bullet}$, GATOT MUDJIONO $^{1}$, AKHMAD RIZALI $^{1}$ \\ ${ }^{1}$ Department of Plant Pest and Diseases, Faculty of Agriculture, Universitas Brawijaya. Jl. Veteran, Malang 65145, East Java, Indonesia. \\ Tel.: +62-341-551611, "email: bambangtri@ub.ac.id \\ ${ }^{2}$ Indonesian Sweetener and Fiber Crops Research Institute. Jl. Raya Karangploso Km. 4, Malang 65152, East Java, Indonesia
}

Manuscript received: 1 June 2021. Revision accepted: 28 August 2021.

\begin{abstract}
Prabowo H, Rahardjo BT, Mudjiono G, Rizali A. 2021. Impact of habitat manipulation on the diversity and abundance of beneficial and pest arthropods in sugarcane ratoon. Biodiversitas 22: 4002-4010. Sugar production in Indonesia faces several challenges such as infestation of pests and diseases that lead to decline in sugarcane production and productivity. In order to overcome the loss of yields from the presence of pests, alternative new approaches are sought by solving of the problem that can have a sustainable impact by applying habitat manipulation. Habitat manipulation changes the diversity and density of arthropods populations in agroecosystem. In the concept of managing agroecosystems with habitat manipulation, it is hoped that the development of agro-ecosystem resilience against pest management will be expected to be suistainable. The results showed that there was an increase in the number of arthropods in the research area for 20 weeks after the management of agro-ecosystems through habitat manipulation. The arthropods in all the traps were dominated by Collembola, Diptera, Coleoptera, Aranea, and Hymenoptera. There were 44 genera that belong to predators and 8 species are belonging to parasitoids. The diversity index of Shannon-Wiener (H '), Simpson Dominance (C) and Species Evenness (E) was not significantly different between treatment and control, but habitat manipulation treatment was able to increase the number of detritivores, predators, parasitoids, and pollinators by $38.81 ; 43.88 ; 58.4$; and $75.35 \%$. The full role of arthropods in the food chain of the sugarcane ecosystem has been identified and efforts are needed to optimize the role of natural enemies in the agroecosystem to maintain ecosystem stability. Habitat manipulation can increase the number of beneficial insect populations in short run, but it might take time to increase their diversity in agroecosystem.
\end{abstract}

Keywords: Diversity, habitat manipulation, pest, sugarcane

\section{INTRODUCTION}

Sugarcane (Saccharum officinarum L.) is one of the important industrial crops grown globally. Sugarcane farming increases income as well as a source of important energy material that can promote sustainable development (Kaab et al. 2019). Sugarcane production in Indonesia contributes Indonesian Rupiah (IDR) 11,500 billion ( $€$ 957,45 million) to the economy (Sulaiman et al. 2019). The industry consists of more than 900,000 farmers and 58 factories often with associated plantations. More than 1.5 million people work in sugarcane-associated industries. Total production is approximately $30 \mathrm{Mt}$ of cane from ca. 430,000 ha of land (Aristya et al. 2020). In Indonesia, sugarcane is widely cultivated on Java, Sumatra and Sulawesi Islands. In 2018, the sugarcane area in Indonesia reached 429.959 hectares, producing a yield of $5,683 \mathrm{~kg}$ ha ${ }^{1}$. However, it still does not meet the national demand for sugar (Directorate General of Estates 2019).

Sugarcane is the kind of plant that is commonly attacked by pests. Pests that are found in sugarcane plantations usually attack the stems and leaves (Goebel et al. 2011; Goebel et al. 2014; Goebel et al. 2011). The sugarcane pests found on stems consist of sugarcane stem borer Chilo spp. (Crambidae: Lepiodoptera), sugarcane pink stem borer, Sesamia inferens Walker (Noctuidae: Lepidoptera), sugarcane gray stem borer Tetramoera schistaceana Snellen (Tortricidae: Lepidoptera), midrib borer, Scirpophaga excerptalis Walker (Crambidae: Lepidoptera), that usually bores into the midrib of the leaf (the growing tip), the sugarcane scale, Aulacaspis tegalensis Zehntner (Diaspididae: Hemiptera), sugarcane mealybug, Saccharicoccus sacchari Cockerell (Pseudococcidae: Hemiptera), and the ricefield rat, Rattus argentiventer Robinson and Kloss (Muridae: Rodentia). Moreover, the sugarcane pests that commonly attack the leaf are sugarcane whitefly, Aleurolobus barodensis Maskell (Aleyrodidae: Hemiptera), sugarcane woolly aphid Ceratovacuna lanigera Zehntner (Aphididae: Hemiptera), sugarcane planthopper Perkinsiella spp. Kirkaldy (Delphacidae: Hemiptera), the island sugarcane planthopper Eumetopina flavipes Muir (Delphacidae: Hemiptera), Javanese grasshopper Valanga nigricornis Burmeister (Acrididae: Orthoptera), and migratory locust Locusta migratoria Meyen (Acrididae: Orthoptera), and rice hispa Dicladispa armigera Olivier (Chrysomelidae: Coleoptera) (Prabowo 2014; Prabowo and Asbani 2014; Omkar and Tripathi 2020). The pests exist due to the unstable ecosystem of the sugarcane ratoons, which can be seen from the low biological diversity (Altieri et al. 2017). The low biological diversity may result from application of sugarcane pests control method by using a chemical pesticide, excessive use of chemical fertilizer and burning of the farmland after harvest. An alternative approach of 
eliminating the problems from the root through habitat manipulation is necessary to sustainably overcome a harvest loss caused by pests. The concept of agroecosystem management by habitat manipulation is anticipated to eventually create an agroecosystem that is highly resilient in preventing pest explosion, so that it can result in sustainable management.

The agroecosystem management through habitat manipulation can use the concept of ecosystem services by optimizing and synergizing the functions of its components. A land with a high biological diversity can enhance soil fertility through activation of soil microorganisms. Moreover, it leads to a balance herbivore population through the role of arthropods that are beneficial for the agroecosystem. Agroecosystem management should consider the supporting factors to the ecosystem services (Roy et al. 2019; Altieri et al. 2017). Some principles in support of ecosystem services apply to agroecosystem management using habitat manipulation, such as 1 . Increasing the conversion rate and optimization of availability and balance of essential nutrients. This principle is possible by a green manure crop rotation. 2 . Stabilizing the soil condition for growing crops through managing organic materials and improving the soil biota. Allowing biomass on land will increase organic materials that will eventually boost the soil biota, which is advantageous for improving soil fertility. 3. Minimizing loss caused by limited water through water management. Water is essential for optimal plant growth so that its timely and considerable availability is very influential for the productivity of the land. Water management can be done by conserving groundwater. 4. The species and genetic diversity in agroecosystem create a natural interaction that is beneficial and a synergy among the agroecosystem components (Reagan et al. 2019; Altieri et al. 2012, Brzozowski and Mazourek 2018).

The agroecosystem management objective is to provide a balanced environment, sustained yields, biologically mediated soil fertility and natural pest regulation through the design of diversified agroecosystems and the use of low-input technologies (Altieri et al. 2017; Alyokhin et al. 2020; Liu et al. 2017; Pearson and Tooker 2017). To obtain such balance, it is necessary to optimize the nutrition recycling and organic materials recovery, conserve water and soil, and control the pest and natural enemies' population so that it can eventually optimize ecosystem services, which can support a healthy agroecosystem. Agroecosystem management via habitat manipulation can conserve the existence of functional arthropods in ecosystems such as decomposers (Collembola, mites, Symphyla), predators (Coleoptera, Araneae, Hymenoptera), and parasitoids (Hymenoptera, Diptera). This will then be able to maximize the role of the ecosystem services to suppress herbivores. Habitat manipulation is expected to increase the diversity and abundance of arthropods in sugarcane ratoons that can eventually improve ecosystem services and create a stable ecosystem and sustainable productivity of sugarcane ratoons. The diverse and abundant arthropods are an important indicator of a stable agroecosystem of sugarcane ratoons (Santos et al. 2017).
Hence, it is crucial to research the impact of habitat manipulation on the diversity and abundance of arthropods in sugarcane ratoons. This research was aimed to identify the impact of habitat manipulation on the diversity and abundance of beneficial and pest arthropods in sugarcane ratoons.

\section{MATERIALS AND METHODS}

\section{Research location and time}

The field research was conducted at a sugarcane plantation in Karangploso Experimental Station, Indonesian Sweetener and Fiber Crops Research Institute, Karangploso Sub-district, Malang Regency with an altitude of $515 \mathrm{~m}$ above sea level (a.s.1.), climate type C3 (Based on the Schmidt-Ferguson Classification). Inceptisol soil type with sandy loam soil texture. It is located in $7^{\circ} 54^{\prime} 28^{\prime \prime} \mathrm{S}$, $112^{\circ} 37^{\prime} 30^{\prime \prime} \mathrm{E}$. The research was also conducted in the Laboratory of Entomology and Phytopathology at the Indonesian Sweetener and Fiber Crops Research Institute of Malang, especially for the clarification and identification processes of the results of arthropods based on the morphospecies.

This research compared the management system of sugarcane ratoon agroecosystem through a habitat manipulation for improving arthropods diversity, which was performed in an area totaling 0.7 ha and sugarcane population of 56,000 plants, with conventional agroecosystem management carried out by farmers in an area totaling 0.7 ha and sugarcane population of 56,000 plants (the area sizes are similar for the two treatments). Both treatments employed the second ratoon cane from PS 862 variety. The assemblages in the agroecosystem management system of sugarcane ratoons via a habitat manipulation and conventional system on the second sugarcane ratoons consisted of the following components (Table 1).

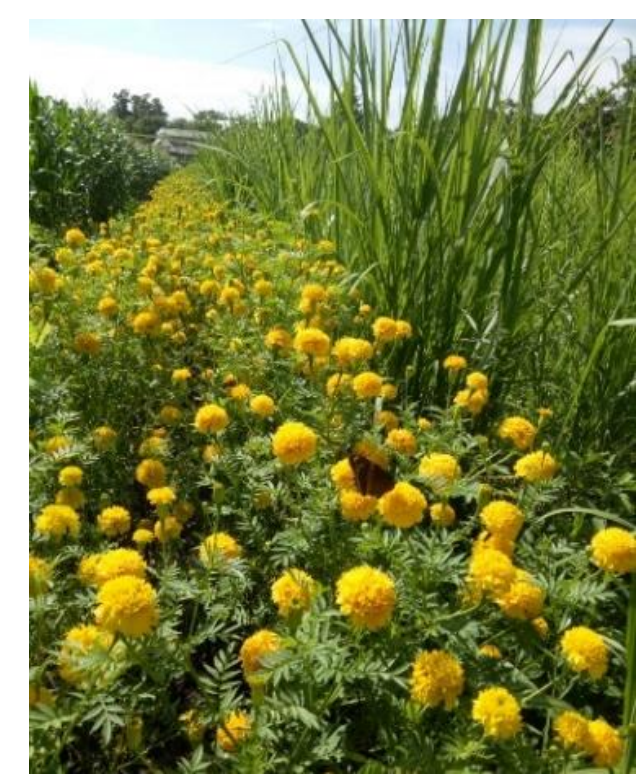

Figure 1. Implementation of habitat manipulation in ratoon sugarcane fields (photo by Heri Prabowo) 
Table 1. The assemblages in the agroecosystem management system of sugarcane ratoons via a habitat manipulation to increase arthropods diversity and conventional system on the second sugarcane ratoons

\begin{tabular}{|c|c|c|}
\hline Stage & Habitat manipulation to improve arthropods diversity & Conventional system (by farmers) \\
\hline $\begin{array}{l}\text { Pre-processing for } \\
\text { soil }\end{array}$ & $\begin{array}{l}\text { Cow manure: goat manure: leaf compost }(5: 3: 2) \text { totaling of } 10 \\
\text { ton } h^{-1}\end{array}$ & Not applicable \\
\hline Pre planting & $\begin{array}{l}\text { Application of PGPR (Pseudomonas fluroscens Flugge } \\
\text { (Pseudomonadaceae: Pseudomonadales), Bacillus subtilis Cohn } \\
\text { (Bacillaceae: Bacillales), and Trichoderma sp. Persoon } \\
\text { (Hypocreaceae: Hypocreales)). }\end{array}$ & Without PGPR \\
\hline Pre planting & Application of mycorrhiza in an amount of 15 gram/plant. & Without mycorrhiza \\
\hline Planting & $\begin{array}{l}\text { Single row planting system with distance from center to center } \\
\text { (PKP) } 100-130 \mathrm{~cm} \text {, single bud planting technique (population of } \\
42.000 / 0,25 \mathrm{ha} \text { ), a balanced NPK fertilizer by the Indonesian } \\
\text { Sweetener and Fiber Crops Research Institute with } 500 \mathrm{~kg} \\
\text { Phonska and } 2,50 \mathrm{~kg} \text { ZA/ha }\end{array}$ & $\begin{array}{l}\text { Single row planting system with distance } \\
\text { from center to center (PKP) } 100-130 \mathrm{~cm} \text {, } \\
\text { single bud planting technique (population } \\
\text { of } 42.000 / 0,25 \mathrm{ha} \text { ), fertilizer dosage of } 500 \\
\mathrm{~kg} \text { Phonska and } 500 \mathrm{~kg} \text { ZA/ha by the } \\
\text { standard dosage for farmers. }\end{array}$ \\
\hline Crop maintenance & $\begin{array}{l}\text { Planting flowers (white buttercup, sunflowers, and compos) as } \\
\text { border plants (Figure 1). }\end{array}$ & Not applicable \\
\hline Crop maintenance & $\begin{array}{l}\text { Multiple cropping (Intercropping) alternately with soybean ( } 1 / 3 \\
\text { part of land), groundnut and sesame ( } 1 / 3 \text { part of the land), } \\
\text { Crotalaria juncea ( } 1 / 3 \text { part of the land), of } 1 \text { row in between } 1-3- \\
\text { month-old sugarcane rows. After the multiple crops are } \\
\text { harvested, then the biomass shall be covered above the soil } \\
\text { surface (around } 16 \text { wet tons/ha). }\end{array}$ & Not applicable \\
\hline Crop maintenance & $\begin{array}{l}\text { Silica spray on } 1,2,3,4 \text { month-old sugarcane with a } \\
\text { concentration of } 5 \mathrm{gr} / \mathrm{L} \text { and spray volume of } 400 \mathrm{~L} / \mathrm{ha} \text {. }\end{array}$ & Not applicable \\
\hline Crop maintenance & $\begin{array}{l}\text { Provision of organic liquid fertilizer (made from cow manure: } \\
\text { goat manure: brown waste in a composition of } 5: 3: 2 \text { ) } \\
\text { concentration } 10 \mathrm{~mL} / \mathrm{L} \text { on } 2 \text {-month old sugarcane. }\end{array}$ & Not applicable \\
\hline Crop maintenance & Weeding was not done to obnoxious weed. & $\begin{array}{l}\text { Weeding and herbicide spray were } \\
\text { performed on all weeds both in between the } \\
\text { plant rows and around the land. }\end{array}$ \\
\hline Crop maintenance & $\begin{array}{l}\text { Beauveria bassiana spray was given on } 2,4 \text {, and } 6 \text {-month old } \\
\text { sugarcane with a concentration of } 200 \mathrm{~g} / \mathrm{L} \text { as preventive and pre- } \\
\text { emptive efforts. }\end{array}$ & Not applicable \\
\hline Defoliation & $\begin{array}{l}\text { Defoliation was conducted and the biomass yield was returned to } \\
\text { the land as cover crops. }\end{array}$ & Defoliation was not conducted \\
\hline Harvesting & The post-harvest burning was not conducted & The post-harvest burning was conducted \\
\hline
\end{tabular}

\section{Arthropods monitoring}

In order to monitor the development of arthropods in the management of ratoon sugarcane agroecosystems through habitat manipulation to increase the diversity of arthropods and conventional systems, monitoring was carried out using several arthropod traps. Monitoring was performed by taking arthropod samples from 4 sample blocks per replication and using 5 replications (total of 20 samples were taken per location ). The plot size was $2 \mathrm{~m} \mathrm{x}$ $2 \mathrm{~m}$ systematically determined by using a diagonal method. Traps included in the monitoring were as follows.

\section{Pitfall trap}

Ground surface arthropods were collected with pitfall traps in the form of plastic cups of $7 \mathrm{~cm}$ in diameter, placed in a systematic random plot, protected from rainwater spills with a tin roof. The pitfall was placed on the net to avoid water disturbances during the irrigation of the sugarcane. Water glass was filled with $\pm 100 \mathrm{ml} 0.1$ percent detergent solution. The timeframe for the installation of the pitfall was 1 week with the installation of the pitfall for 168 hours and, if full, the harvesting of the arthropods took place. Samples were taken once a week using plastic and identified in the ISFCRI Pest laboratory following the insect identification book (Capinera 2008; Gullat and Cranston 2010; Farrow (2016), Kalshoven (1981), Hill (2008), and Emden (2013).

\section{Yellow pan trap}

A collection was carried out using yellow-pan traps with diameter of $12 \mathrm{~cm}$ to monitor the presence of flying arthropods. The pan was filled with 0.1 percent detergent solution covered with plastic with a slope of about $45^{\circ}$ to protect it from rainwater entering the pan trap. Data were collected at intervals of 1 week. Samples were taken using plastic and identified in the ISFCRI Pest laboratory on the basis of the insect identification book written by Capinera (2008), Gullant and Cranston (2010), Farrow (2016), Kalshoven (1981), Hill (2008), and Emden (2013). 


\section{D-Vac modified}

The arthropods in the plants were visually observed and then collected using modified D-Vac. The removal of the arthropod was performed at each point. Samples were taken once a week using plastic and identified in the ISFRCRI Pest laboratory on the basis of the insect identification book written by Capinera (2008), Gullant and Cranston (2010), Farrow (2016), Kalshoven (1981), Hill (2008), and Emden (2013). Yellow sticky traps and Yellow paper traps

Flying arthropods were collected using Yellow Sticky Traps with yellow paper traps with an adhesive size of 11 $\mathrm{cm} \times 16 \mathrm{~cm}$, placed in a systematic random pattern with 20 traps every 0.25 ha. Samples were taken once a week using plastic and identified in the ISFCRI Pest Laboratory on the basis of the insect identification book written by Capinera (2008), Gullant and Cranston (2010), Farrow (2016), Kalshoven (1981), Hill (2008), and Emden (2013).

\section{Modified Berlese-Tullgren funnel}

Soil arthropods were collected by taking 500 grams of soil samples for arthropod extraction. Samples were taken once a week with plastic and the arthropods were extracted using a modified Berlese-Tullgren funnel in the ISFCRI pest laboratory. The arthropods obtained were then identified in the ISFCRI Pest Laboratory on the basis of the insect identification book written by Capinera (2008), Gullant and Cranston (2010), Farrow (2016), Kalshoven (1981), Hill (2008), and Emden (2013).

The arthropods obtained were identified at least at the family/morpho-species level based on the insect identification book written by Capinera (2008), Gullant and Cranston (2010), Farrow (2016), Kalshoven (1981), Hill (2008), and Emden (2013). Population data per species were then converted to the Simpson (D) Dominance Index, the Shannon-Wiener Diversity Index $\left(\mathrm{H}^{\prime}\right)$, the Pielou Similarity Level (E) and the Margalef Species Richness (R) (Ludwig \& Reynold 1988) using Biodiversity Professional Software by McAleece et al. (1997). The conversion results are in the form of parametric data, assuming that normality is met, and then processed using an unpaired t-test. A decision-making level of 95 percent was used for each test.

\section{RESULTS AND DISCUSSION}

\section{Abundance of arthropods population in the manipulated habitat of sugarcane ratoon fields}

Detrivorus population was found to be the most dominant species compared to predators, parasitoids, pollinators, and herbivores (Figure 2). In the manipulated ratoon sugarcane habitat, the number of detritivores, predators, parasitoids, pollinators, and herbivores was higher than those in non-manipulated habitat fields. The population of detritivores, predators, parasitoids, pollinators, and herbivores was greater by $38.81 ; 43.88$;
$58.40 ; 75.35 ; 22.15 \%$, respectively, as compared to the population encountered in the control plots. The increase in the functional role of arthropods in the agroecosystem is influenced by the implementation of habitat manipulation. The abundance and the existence of arthropods seemed to be influenced by the existence of habitat manipulation, as shown by other studies (Krakos et al. 2011; Allifiah et al. 2013, Silveira et al.2009). A study conducted by Saona et al (2011) showed that habitat manipulation increases the diversity of predators in the area where it was planted. Meanwhile, carnivorous arthropods, including spiders, were more abundant in the manipulated habitat plots than in the control plots (Pearsons and Tooker 2017). Habitat manipulation had a significant effect on the diversity of ground-dwelling arthropods, including some key predators for the control of pests in agroecosystem, such as ants and spiders (De Pedro et al. 2020). Common agricultural practices such as plowing, the removal of ruderal plants, and the use of fertilizers altered soil conditions and had a significant impact on the diversity and abundance of epigeal arthropods, including many species that play an important role in the regulation of plant pests. Habitat manipulation preserved food availability to natural enemies and improved their performance. Nectar and honeydew are known to enhance the life span and fecundity of natural enemies. Agroecological practices through habitat manipulation may contribute to the maintenance of local biodiversity and the importance of including farmlands in the plans for the conservation of the species (Roy et al. 2019; Lungren et al. 2006).

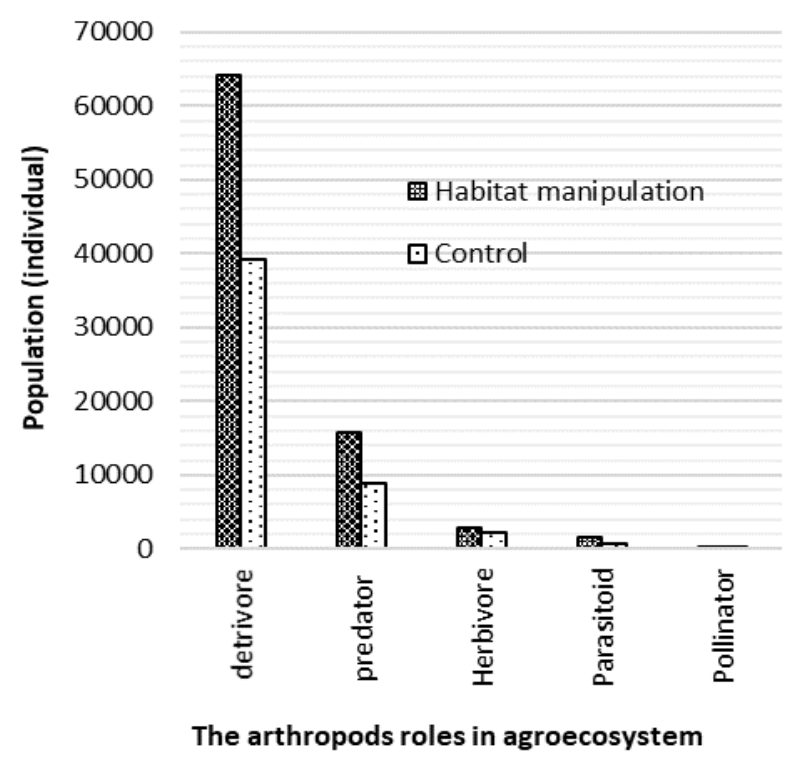

Figure 2. Composition of each functional category of arthropods sampled from sugarcane ratoon plantation. (The average in each arthropods category followed by the same letter is not significantly different by $\mathrm{T}$ Test $(\alpha=5 \%))$. 
Table 2. Population of arthropods trapped in the habitat manipulation in sugarcane fields for 20 weeks after ratoon.

\begin{tabular}{|c|c|c|c|c|c|c|c|}
\hline \multirow[b]{2}{*}{ Family } & \multirow[b]{2}{*}{ Genus } & \multicolumn{5}{|c|}{ Number of Individuals } & \multirow[b]{2}{*}{ Total } \\
\hline & & $\begin{array}{c}\text { Yellow Sticky } \\
\text { Trap }\end{array}$ & $\begin{array}{c}\text { Yellow Pan } \\
\text { Trap }\end{array}$ & Pitfall Trap & $\begin{array}{c}\text { Barlease Tulgren } \\
\text { Trap }\end{array}$ & $\begin{array}{c}\text { modified D-Vac } \\
\text { Trap }\end{array}$ & \\
\hline Diptera. & & & & & & & \\
\hline Culicidae & Culex & 2,227 & & & & 2,311 & 4,538 \\
\hline Tephritidae & Bactrocera & 1,692 & & & & 1,889 & 3,581 \\
\hline Dolichopodidae & Condylostylus & 886 & & & & 1,014 & 1,900 \\
\hline Tephritidae & Atherigona & 511 & & & & 518 & 1,029 \\
\hline Muscidae & Musca & 569 & & & & 573 & 1,142 \\
\hline Drosophilidae & Drosophila & 1,697 & & & & 1,677 & 3,374 \\
\hline Sarchopagidae & Sarcophaga & 401 & & & & 22 & 423 \\
\hline Micropezidae & Mimegralla & 22 & & & & & 22 \\
\hline Caliporidae & Lucilia & 15 & & & & & 15 \\
\hline Syrpidae & Helophilus & & & & & & 2 \\
\hline Tachinidae & Diatraeophaga & 1 & & & & & 1 \\
\hline Orthoptera & & & & & & & \\
\hline Acrididae & Valanga & 280 & 137 & 245 & & 13 & 675 \\
\hline Gryllidae & Gryllotalpa & & 109 & 127 & & & 236 \\
\hline Gryllidae & Gryllus & & 125 & 108 & & & 233 \\
\hline Blattaria & & & & & & & \\
\hline Blattidae & Parcoblatta & 294 & & & 310 & 106 & 710 \\
\hline Coleoptera & & & & & & & \\
\hline Carabidae & Pericalus & 213 & 502 & 702 & & 273 & 1,690 \\
\hline Carabidae & Calosoma & 21 & 6 & 6 & & 283 & 316 \\
\hline Chrysomelidae & Eulema & 17 & & 195 & & 203 & 415 \\
\hline Carabidae & Lebia & & 115 & & & & 115 \\
\hline Scarabaeidae & Phyllophaga & 18 & 115 & 215 & & 180 & 528 \\
\hline Staphylinidae & Paederus & 23 & 13 & & & & 36 \\
\hline Cincindelidae & Cicindela & 14 & & 97 & & 197 & 308 \\
\hline Coccinellidae & Scymnus & 21 & & & & 250 & 271 \\
\hline Coccinellidae & & 15 & & & & 260 & 275 \\
\hline Staphylinidae & Euconnus & & & 78 & 112 & & 190 \\
\hline Aranae & & & & & & & \\
\hline Atypena & - & 21 & 25 & & & 99 & 145 \\
\hline Lycosa & - & 36 & 25 & 112 & 97 & 239 & 509 \\
\hline Tetragnatha & - & & & 35 & 36 & & 71 \\
\hline Homoptera & & & & & & & \\
\hline Aphididae & Aphis & 21 & & & & 153 & 174 \\
\hline Cicadelidae & Nephotettix & 38 & & & & 39 & 77 \\
\hline Thysanoptera & & & & & & & \\
\hline Thripidae & Fulmekiola & 5 & & & & 174 & 179 \\
\hline Lepidoptera & & & & & & & \\
\hline Hesperiidae & Pelopidas & 28 & & & & 39 & 67 \\
\hline Erebidae & Amata & 14 & & & & 273 & 287 \\
\hline Odonata & & & & & & & \\
\hline Anax & & 3 & & & & & 3 \\
\hline Hymenoptera & & & & & & & \\
\hline Diapriidae & Idiotypa & 88 & & & & & 88 \\
\hline Evaniidae & Evaniella & 123 & & & & & 123 \\
\hline Scelionidae & Telenomus & 112 & & & & & 112 \\
\hline Braconidae & Cotesia & 12 & & & & & 12 \\
\hline Braconidae & Apanteles & 9 & & & & & 9 \\
\hline Trichogrammatidae & Trichogramma & 1 & & & & & 1 \\
\hline Sphecidae & Chalybion & 63 & & & & & 63 \\
\hline Vespidae & Vespulla & 22 & & & & & 22 \\
\hline Ichneumonidae & Isotima & 142 & & & & & 142 \\
\hline Formicidae & Myrmica & & & 932 & 1,739 & 104 & 2,775 \\
\hline Formicidae & Solenopsis & & & 593 & 491 & 98 & 1,182 \\
\hline Formicidae & Dolichoderus & & & 649 & 383 & 184 & 1,216 \\
\hline Collembola & & & & & & & \\
\hline Brachystomellidae & Brachystomella & & 1,498 & 1,695 & 1,567 & & 4,760 \\
\hline Entomobridae & Alloscopus & & 1,877 & 1,586 & 1,633 & & 5,096 \\
\hline Isotomidae & Folsomides & & 1,111 & 809 & 941 & & 2,861 \\
\hline Heteronomous & & & 1,091 & 740 & 368 & & 2,199 \\
\hline Sminthuridae & Sminturides & & 1,213 & 116 & 402 & & 1,731 \\
\hline Neaurini & - & & 54 & 367 & 115 & & 482 \\
\hline Vitronura & - & & 9 & 25 & & & 34 \\
\hline Sympylla & & & & & & & \\
\hline Sympylla & - & & & 319 & 159 & & 478 \\
\hline Chilopoda & & & & & & & \\
\hline Geophilomorpha & - & & & 92 & 236 & & 328 \\
\hline Acarina & & & & & & & \\
\hline Oribatid & - & & & 319 & 512 & & 831 \\
\hline $\begin{array}{l}\text { Hypoaspis } \\
\text { Trombidium }\end{array}$ & - & & & 71 & $\begin{array}{l}021 \\
152\end{array}$ & & 223 \\
\hline Dermaptera & & & & & & & \\
\hline Exypnus & - & & & 16 & 8 & & 24 \\
\hline Isoptera & & & & & & & \\
\hline Macrotermes & - & & & 17 & 5 & & 22 \\
\hline $\begin{array}{l}\text { Isopoda } \\
\text { Armadillidium }\end{array}$ & - & & & 270 & 18 & & 288 \\
\hline Diplura & - & & & & 1 & & 1 \\
\hline Pseudoscorpion & & & & & & & \\
\hline $\begin{array}{l}\text { Wyochernes } \\
\text { Total }\end{array}$ & - & & & & $\begin{array}{l}3 \\
9915\end{array}$ & & 3 \\
\hline Total & & 9.677 & 8025 &, 806 & 9,915 & 11,171 & \\
\hline
\end{tabular}


Table 3. Population of arthropods trapped in the conventional system (without habitat manipulation treatment) in sugarcane fields for 20 weeks after ratoon

\begin{tabular}{|c|c|c|c|c|c|c|c|}
\hline \multirow[b]{2}{*}{ Family } & \multirow[b]{2}{*}{ Genus } & \multicolumn{5}{|c|}{ Number of Individuals } & \multirow[b]{2}{*}{ Total } \\
\hline & & $\begin{array}{c}\text { Yellow Sticky } \\
\text { Trap }\end{array}$ & $\begin{array}{c}\text { Yellow Pan } \\
\text { Trap }\end{array}$ & Pitfall Trap & $\begin{array}{c}\text { Barlease Tulgren } \\
\text { Trap }\end{array}$ & $\begin{array}{c}\text { modified D-Vac } \\
\text { Trap }\end{array}$ & \\
\hline Diptera & & & & & & & \\
\hline Culicidae & Culex & 2,608 & & & & 2,811 & 5,419 \\
\hline Tephritidae & Bactrocera & 1,612 & & & & 1,883 & 3,495 \\
\hline Dolichopodidae & Condylostylus & 926 & & & & 1,117 & 2,043 \\
\hline Tephritidae & Atherigona & 579 & & & & 565 & 1,144 \\
\hline Muscidae & Musca & 659 & & & & 637 & 1,296 \\
\hline Drosophilidae & Drosophila & 1,686 & & & & 1,673 & 3,359 \\
\hline Sarchopagidae & Sarcophaga & 464 & & & & 114 & 578 \\
\hline Micropezidae & Mimegralla & 114 & & & & & 114 \\
\hline Caliporidae & Lucilia & 37 & & & & & 37 \\
\hline Syrphidae & Helophilus & 0 & & & & & 0 \\
\hline Tachinidae & Diatraeophaga & 0 & & & & & 0 \\
\hline Orthoptera & 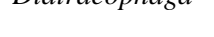 & & & & & & \\
\hline Acrididae & Valanga & 287 & 25 & 252 & & 45 & 609 \\
\hline Gryllidae & Gryllotalpa & & 55 & 158 & & TJ & 213 \\
\hline Gryllidae & Gryllus & & 119 & 64 & & & 183 \\
\hline Blattaria & & & & & & & \\
\hline Blattidae & Parcoblatta & 313 & & & 288 & 86 & 687 \\
\hline Coleoptera & & & & & & & \\
\hline Carabidae & Pericalus & 235 & 391 & 681 & & 298 & 1,605 \\
\hline Carabidae & Calosoma & 16 & 0 & 0 & & 304 & 320 \\
\hline Chrysomelidae & Eulema & 9 & & 119 & & 226 & 354 \\
\hline Carabidae & Lebia & S & 107 & & & & 107 \\
\hline Scarabaeidae & Phyllophaga & 42 & 96 & 188 & & 203 & 529 \\
\hline Staphylinidae & Paederus & 22 & 9 & & & & 31 \\
\hline Cincindelidae & Cicindela & 12 & & 65 & & 223 & 300 \\
\hline Coccinellidae & Scymnus & 16 & & & & 275 & 291 \\
\hline Coccinellidae & & 5 & & & & 281 & 286 \\
\hline Staphylinidae & Euconnus & & & 55 & 109 & & 164 \\
\hline Aranae & & & & & & & \\
\hline Atypena & - & 39 & 167 & & & 114 & 320 \\
\hline Lycosa & - & 35 & 92 & 96 & 124 & 260 & 607 \\
\hline Tetragnatha & - & & & 45 & 18 & & 63 \\
\hline Homoptera & & & & & & & \\
\hline Aphididae & Aphis & 11 & & & & 179 & 190 \\
\hline Cicadelidae & Nephotettix & 32 & & & & 54 & 86 \\
\hline Thysanoptera & & & & & & & \\
\hline Thripidae & Fulmekiola & 5 & & & & 199 & 204 \\
\hline Lepidoptera & & & & & & & \\
\hline Hesperiidae & Pelopidas & 35 & & & & & 35 \\
\hline Erebidae & Amata & 13 & & & & 298 & 311 \\
\hline Odonata & & & & & & & \\
\hline Anax & & 1 & & & & & 1 \\
\hline Hymenoptera & & & & & & & \\
\hline Diapriidae & Idiotypa & 75 & & & & & 75 \\
\hline Evaniidae & Evaniella & 212 & & & & & 212 \\
\hline Scelionidae & Telenomus & 204 & & & & & 204 \\
\hline Braconidae & Cotesia & 21 & & & & & 21 \\
\hline Braconidae & Apanteles & 12 & & & & & 12 \\
\hline Trichogrammatidae & Trichogramma & 1 & & & & & 1 \\
\hline Sphecidae & Chalybion & 54 & & & & & 54 \\
\hline Vespidae & Vespulla & 20 & & & & & 20 \\
\hline Ichneumonidae & Isotima & 98 & & & & & 98 \\
\hline Formicidae & Myrmica & & & 927 & 1,773 & 127 & 2,827 \\
\hline Formicidae & Solenopsis & & & 557 & 391 & 124 & 1,072 \\
\hline Formicidae & Dolichoderus & & & 563 & 366 & 205 & 1,134 \\
\hline Collembola & & & & & & & \\
\hline Brachystomellidae & Brachystomella & & 1,956 & 2,243 & 1,520 & & 5,719 \\
\hline Entomobridae & Alloscopus & & 1,883 & 1,582 & 1,661 & & 5,126 \\
\hline Isotomidae & Folsomides & & 1,230 & 887 & 973 & & 3,090 \\
\hline Heteronomous & & & 1,126 & 850 & 254 & & 2,230 \\
\hline Sminthuridae & Sminturides & & 1,250 & 125 & 255 & & 1,630 \\
\hline Neaurini & - & & 38 & 443 & 80 & & 561 \\
\hline Vitronura & - & & 18 & 53 & & & 71 \\
\hline Sympylla & & & & & & & \\
\hline Sympylla & - & & & 293 & 26 & & 319 \\
\hline Chilopoda & & & & & & & \\
\hline $\begin{array}{l}\text { Geophilomorpha } \\
\text { Acarina }\end{array}$ & - & & & 83 & 228 & & 311 \\
\hline Oribatid & - & & & 293 & 477 & & 770 \\
\hline Hypoaspis & - & & & 301 & 687 & & 988 \\
\hline Trombidium & - & & & 87 & 150 & & 237 \\
\hline Dermaptera & & & & & & & \\
\hline $\begin{array}{l}\text { Exypnus } \\
\text { Isoptera }\end{array}$ & - & & & 14 & 2 & & 16 \\
\hline $\begin{array}{l}\text { Isoptera } \\
\text { Macrotermes }\end{array}$ & - & & & 21 & 4 & & 25 \\
\hline $\begin{array}{l}\text { Isopoda } \\
\text { Istiles }\end{array}$ & & & & & & & \\
\hline Armadillidium & - & & & 301 & 32 & & 333 \\
\hline Diplura & - & & & & 1 & & 1 \\
\hline Pseudoscorpion & & & & & & & \\
\hline $\begin{array}{l}\text { Wyochernes } \\
\text { Total }\end{array}$ & - & 1.0510 & 8,562 & 11,346 & $\begin{array}{c}1 \\
9,420\end{array}$ & 12,301 & 1 \\
\hline
\end{tabular}




\section{Diversity of arthropods on sugarcane ratoon with habitat manipulation}

Agroecological practices, such as habitat manipulation, are known to contribute to the preservation of local biodiversity in farming systems (Albrecht et al. 2020; Lami et al. 2021; Paiola et al. 2020). The change in the diversity of agroecosystems is the parameter being evaluated. Ecosystem diversity is divided into three levels: genetic, species, and community (ecosystem) diversity. This diversity determines the strength of the population adaptation that will be part of the species interaction. Diversity is made up of two distinct components, namely species richness and evenness. The species richness is the total number of species, while the distribution of abundance (e.g. number of individuals, biomass, etc.) is the same for each species (Ludwig and Reynolds 1988).

A total of 101.733 individuals (Table 2 and 3) of arthropods were collected during the sugarcane plantation phases. They were in six classes, eight teen orders. The results of the diversity assessment in the research area are as follows:

\section{Index of species richness $(R)$}

The richness of arthropod species using the Margalef index showed the results of the analysis that habitat manipulation treatment had a higher value than control with a value of 6,5784 (Table 4).. The species richness index of land with habitat manipulation is of the highest category. This may be due to a number of factors, such as the even distribution of species followed by an even number of individuals, the high diversity of species, the presence of species that do not predominate in the community, which is indicated by the lack of a striking comparison of the number of individuals between one species and another, and limiting factors such as unfavorable environmental conditions.

\section{Index of species diversity $\left(H^{\prime}\right)$}

The Diversity Index combines the richness and evenness of the species in a single value. Diversity indices are often difficult to interpret because the same index value can result from different combinations of species richness and evenness. The same diversity value can result from a community with a low level of species richness but a high level of evenness or a community with a high level of species richness but a low level of evenness. The diversity of species used in this study is the Shannon Wiener Index $\left(\mathrm{H}^{\prime}\right)$. The richness of arthropod species used in the Shannon Wiener Index $\left(\mathrm{H}^{\prime}\right)$ shows that the value of habitat manipulation treatment in the medium category is 1,412 (Table 4). The range of values for the diversity index $\left(\mathrm{H}^{\prime}\right)$ is (Wheater et al, 2011): a. $\mathrm{H}^{\prime}<1=$ low diversity; b. $1 \leq \mathrm{H}^{\prime} \leq 3$ $=$ moderate diversity; $\mathrm{H}^{\prime}>3=$ high diversity.

A community is said to have a high diversity of species if there are many species with a relatively even number of individuals. In other words, if a community consists of only a few species with an uneven number of individuals, then there is low diversity in the community. The community is included in the medium category due to the dominance of a particular genus so that the distribution of the genus in the ecosystem is not evenly distributed.

\section{Index of Evenness $(E)$}

The value of the evenness index (e) indicates that the habitat manipulation value is higher than the control value with a value of 0.435 . (distressed category) (Table 4). The evenness index is used to determine how stable a species is in maintaining its ability to sustain its species. That is, the higher the value of equality, the more stable the diversity of species in the community. In the same way, vice versa, if the equal value is lower, the stability of the diversity of species in the community will also be lower. According to Krebs (1972), when assessed from a community perspective, the criteria for an evenness index are categorized as follows: $0<\mathrm{e} \leq 0.5$ is a depressed community; $0.5<\mathrm{e} \leq 0.75$ is an unstable community; and $0.75<\mathrm{e} \leq 1$ is a stable community. Habitat manipulation of land communities has a fairly even and uneven level of equality, including the criterion of a depressed community. This is possible because the level of the population that is classified as small for each species with a distribution of the number of individuals of each species is not the same, so that there is a tendency for one or two species to dominate.

\section{Index of Dominance}

The value of the dominant index (C) due to habitat manipulation can be seen in Table 3. The value of the dominant index value shows that the habitat manipulation value is higher than the control value. The Dominance Index describes the presence or absence of a dominant gene or species in the community of the ecosystem. Treatment may increase the number and diversity of species in the ecosystem. The index value of dominance is closely related to the index value of diversity, the higher the index value of dominance, the lower the index value of diversity, and vice versa (Odum and Barret 2005). The predominance of arthropods on land with habitat manipulation is in the low dominance category with a value of 0.1352 (Table 4). Dominance is divided into low $(0<\mathrm{C} \leq 0.5)$, medium $(0.5$ $<\mathrm{C} \leq 0.75)$ and high $(0.75<\mathrm{C} \leq 1.00)$ dominance (Odum and Barret 2005). The Shannon-Wiener diversity index (H'), Simpson Dominance (C) and Species Evenness (E) indices were not significantly different among the treatment and control. Habitat manipulation is expected to increase agroecosystem diversity in the long term. In the short term, habitat manipulation treatment can only increase the number of functional arthropods in the agroecosystem. In the future, habitat manipulation will evolve to be applied in various places to increase the diversity of agroecosystems. (Sommaggio, 2018) found a significantly higher activity and density of isopods, staphylinids, carabids and grillids in the soil surface of a vineyard with several types of habitat manipulation, relative to the control, which was exposed to periodical tillage. (Rieux et al. 2018) also reported a higher diversity index for arthropods on habitat manipulation land than on bare ground and natural vegetation cover in French pear orchards. 
Table 4. Domination index, diversity index, level of similarity, and species richness in sugarcane fields for 20 weeks after ratoon

\begin{tabular}{|c|c|c|c|c|}
\hline & $\begin{array}{c}\text { Simpson's } \\
\text { dominance index }\end{array}$ & $\begin{array}{l}\text { Diversity index }\left(\mathrm{H}^{\prime}\right) \\
\text { from Shannon-Wiener }\end{array}$ & $\begin{array}{c}\text { Similarity level (E) from } \\
\text { Pielou }\end{array}$ & $\begin{array}{c}\text { Species richness (R) from } \\
\text { Margalef }\end{array}$ \\
\hline $\begin{array}{l}\text { Habitat manipulation } \\
\text { fields }\end{array}$ & $\begin{array}{l}0.1352 \\
\text { (low dominance). }\end{array}$ & 1.4124 (low diversity) & $\begin{array}{l}0.434578 \\
\text { (distressed category) }\end{array}$ & $\begin{array}{l}6.5784 \\
\text { (high species richness) }\end{array}$ \\
\hline Control & $\begin{array}{l}0.135 \\
\text { (low dominance). }\end{array}$ & $\begin{array}{l}1.399 \\
\text { (low diversity) }\end{array}$ & $\begin{array}{l}0.430716 \\
\text { (distressed category) }\end{array}$ & $\begin{array}{l}6.5374 \\
\text { (high species richness) }\end{array}$ \\
\hline
\end{tabular}

The results showed that there was an increase in the number of arthropods in the research area for 20 weeks after the management of agro-ecosystems through habitat manipulation. The arthropods in all the traps were dominated by Collembola, Diptera, Coleoptera, Aranea, and Hymenoptera. Most of the arthropods identified were thought to act as decomposers, herbivores, predators, and parasitoids (Tables 1 and 2, Figure 2). The results showed that the natural enemy communities in ratoon sugarcane cultivation with habitat manipulation could be grouped into predatory arthropods and parasitoids. From the results, observations note that there are 44 genera that act as predators and 8 species as parasitoids.

Ground-dwelling arthropods are an essential part of the biodiversity of most terrestrial environments. Several species are common in most surveys undertaken in various environments, such as Collembola, Carabids, Staphylinids, Acari, Myriapoda, Araneae, and Formicidae. Epigeic arthropods affect ecosystem function by including a wide range of trophic guilds and ecological activities. Many ground-dwelling arthropods do not spend their entire lives on the soil surface, instead commuting between the ground and plant aerial parts. This is phenomenon can be found for many large predator species, such as Formicidae and Araneae groups, which are common in terrestrial ecosystems and play an important role in regulating the number of herbivores on plants. Furthermore, due to their contact with commuting species, many solely grounddwelling arthropods may influence the population dynamics of aerial herbivores through cascading effects created by "top-down" regulating processes (Jabbour et al. 2016; Simao et al. 2015; Stefani et al. 2015). Habitat manipulation provides suitable habitat for natural enemies and can support conservation activities in maintaining ecosystems in agricultural areas. So that it can increase the population of natural enemies, both predators, and parasitoids (Rahardjo et al. 2018). The full role of arthropods in the food chain of the sugarcane ratoon ecosystem has been identified and efforts are needed to optimize the role of natural enemies in the sugarcane ratoon ecosystem to maintain ecosystem stability. Habitat manipulation treatment was able to increase the number of detritivores, predators, parasitoids, and pollinators by 38.81; 43.88; 58.4; and 75.35\%. Habitat manipulation treatment has been able to increase the number of beneficial insect populations, but it takes time to increase the diversity of the sugarcane ratoon ecosystem.

\section{REFERENCES}

Albrecht M, Kleijn D. Williams NM. Tschumi M. Blaauw BR. Bommarco R. 2020. The effectiveness of flower strips and hedgerows on pest control. pollination services and crop yield: a quantitative synthesis. Ecol Lett 23 (10): 1488-98. DOI: 10.1111/ele.13576.

Alyokhin A, Nault B, Brown B. 2020. Soil conservation practices for insect pest management in highly disturbed agroecosystems - a review. Entomol Exp Appl 168 (1): 7-27. DOI: 10.1111/eea.12863.

Allifiah ANAF, Yanuwiadi W, Gama ZP dan Leksono AS. 2013. Refugia sebagai mikrohabitat untuk meningkatkan peran musuh alami di lahan pertanian. Prosiding FMIPA Universitas Pattimura Page: 113-116. DOI: $10.29405 /$ solma.v9i1.3108.

Altieri MA, Ponti L. Nicholls CI. 2012. Soil fertility. biodiversity and pest management. In: Gurr GM. Wratten SD. Snyder WE. Read DMY. (eds.). Biodiversity and Insect Pests: Key Issues for Sustainable Management. John Wiley \& Sons. Chichester. UK. DOI: 10.1002/9781118231838.

Altieri MA, Nicholls CI. Montalba R. 2017. Technological approaches to sustainable agriculture at a crossroads: An agroecological perspective. Sustain. 9 (3): 1-13. DOI: 10.3390/su9030349.

Aristya GR, Masyhuri H, Kasiamdari RS, Prabowo H, Husna N. 2020. Screening and characterization of molecular markers for sugarcane (Saccharum officinarum L.) resistance to shoot borer pest, IOP Conf Ser Earth Environ Sci 1: 468. DOI: 10.1088/17551315/468/1/012018.

Brzozowski L. Mazourek M. 2018. A sustainable agricultural future relies on the transition to organic agroecological pest management. Sustainability 10 (6): 2023. DOI: 10.3390/su10062023

Capinera JL. 2008. Encyclopedia of Entomology, 2nd edition, Springer Science+Business Media B.V., New York. DOI: 10.1007/978-14020-6359-6.

De Pedro, Perera-Fernández L, López-Gallego LG, Pérez-Marcos M Sanchez JA. 2020. The effect of cover crops on the biodiversity and abundance of ground-dwelling arthropods in a Mediterranean Pear orchard. Agronomy 10. DOI:10.3390/agronomy10040580.

Directorate General of Estates. 2019. Statistik Perkebunan Indonesia Tahun 2018-2020. Direktorat Jenderal Perkebunan, Jakarta. [Indonesian]

Emden HV. 2013. Handbook of Agricultural Entomology, Wiley, John \& Sons, UK. DOI: 10.1002/9781118469347

Farrow, RA. 2016. Insects of south-eastern Australia: an ecological and behavioural guide. CSIRO Publishing. Australia. DOI: $10.1086 / 690893$

Goebel FR, Achadian E, Kristini A, Sochib M, Adi H. 2011. Investigation of crop losses due to moth borers in indonesia. Proc Aust Soc Sugarcane Technol 33: 1-9.

Goebel FR, Achadian E, Mcguire P. 2014. The economic impact of sugarcane moth borers in Indonesia, Sugar Tech 16 (4): 405-410. DOI: 10.1007/s12355-013-0281-2.

Goebel FR, Sallam N. 2011. New pest threats for sugarcane in the new bioeconomy and how to manage them, Curr Opin Environ Sustain 3 (1): 81-89. DOI: 10.1016/j.cosust.2010.12.005.

Gullant, PJ, Cranston PS. 2010. The Insects an Outline of Entomology, 4th ed, Wiley Blackwell Publishing, NY. DOI: 10.1093/ae/tmw008.

Hill DS. 2008. Pests of Crops in Warmer Climates and Their Control, Springer, UK. DOI: 10.1007/978-1-4020-6738-9.

Kaab A, Sharifi M. Mobli H. Nabavi-Pelesaraei A. Chau K wing. 2019. Use of optimization techniques for energy use efficiency and environmental life cycle assessment modification in sugarcane production. Energy 181: 1298-320. DOI: 10.1016/j.energy.2019.06.002. 
Jabbour R, Pisani-Gareau, T, Smith RG, Mullen C, Barbercheck M. 2016. Cover crop and tillage intensities alter ground-dwelling arthropod communities during the transition to organic production. Renew Agric Food Syst 31: 361-374. DOI: 10.1017/S1742170515000290.

Kalshoven LGE. 1981. The Pest of Crops in Indonesia. Laan PA van der, penerjemah. Ichtiar Baru van Hoeve, Jakarta.

Krebs CJ and Kenney AJ. 2011. Program for Ecological Methodology, 2nd ed. Dept of Zoology University of British, Columbia, Vancouver, Canada.

Lami F. Bartomeus I. Nardi D. Beduschi T. Boscutti F. Pantini P. 2021. Species-habitat networks elucidate landscape effects on habitat specialisation of natural enemies and pollinators. Ecol Lett 24 (2): 288-297. DOI: 10.1111 /ele.13642.

Liu JL, Ren W, Zhao WZ, Li FR. 2017. Cropping systems alter the biodiversity of ground- and soil-dwelling herbivorous and predatory arthropods in a desert agroecosystem: Implications for pest biocontrol. Agric Ecosyst Environ 266: 109-21. DOI: 10.1016/j.agee.2018.07.023.

Ludwig JA and Reynolds JF. 1988. Statistical ecology: a primer methods and computing. Intl J Insect Sci 3: 11-21.

McAleece N, Gage JDG, Lambshead PJD, Paterson GLJ. 1997. Biodiversity professional statistics analysis software. Jointly developed by the Scottish Association for Marine Science and the Natural History Museum, London.

Omkar, Tripathi AK. 2020. Sucking pests of sugarcane. In: Omkar (Eds) Sucking Pests of Crops, $1^{\text {st }}$ ed. Springer Nature, Singapore. DOI: 10.1007/978-981-15-6149-8.

Pearsons KA, Tooker JF. 2017. In-field habitat management to optimize pest control of novel soil communities in agroecosystems, Insects 8 . DOI: $10.3390 /$ insects 8030082 .

Paiola A. Assandri G. Brambilla M. Zottini M. Pedrini P. Nascimbene J. 2020. Exploring the potential of vineyards for biodiversity conservation and delivery of biodiversity-mediated ecosystem services: A global-scale systematic review. Sci Total Environ 706: 135839. DOI: 10.1016/j.scitotenv.2019.135839.

Pearsons KA, Tooker JF. 2017. In-field habitat management to optimize pest control of novel soil communities in agroecosystems. Insects 8 (3): 82. DOI: $10.3390 /$ insects 8030082 .

Prabowo H, Asbani N. 2014. Hama kutu putih (Ceratovacuna lanigera) dan pengendaliannya. Warta Puslitbang Perkebunan 20 (2): 1-4 [Indonesian]
Prabowo H, Supriyadi. 2014. Intensitas serangan penggerek pucuk tebu (Scirpophaga excerptalis Walker) pada lahan persemaian tebu di Kebun Percobaan Muktiharjo, Pati, Jawa Tengah. Prosiding Semiloka Pemanis dan Serat, Malang. [Indonesian]

Rahardjo B,T, Ikawati S, Prasdianata M, Tarno H. 2018. Effect of refugia on spatial and temporal distribution of arthropods on rice agroecosystem (Oryza sativa Linn). Asian J Crop Sci 10 (3): 134-140. DOI: 10.3923/ajcs.2018.134.140.

Reagan TE, Mulcahy MM. 2019. Interaction of cultural, biological, and varietal controls for management of stalk borers in Louisiana Sugarcane, Insects 10 (9): 305. DOI: 10.3390/insects10090305.

Rieux R, Simon S, Defrance H. 2018. Role of hedgerows and ground cover management on arthropod populations in pear orchards, Agric. Ecosyst Environ 73: 119-127.

Roy S, Jaiswal AK, Sushil SN et al. 2019. Landscape-Based Habitat Engineering for Sugarcane Ecosystem: A Green Technological Option for Pest Management, Sugar Tech 21:213-226. DOI: 10.1007/s12355-019-00705-0.

Santos LAO, Naranjo-Guevara N, Fernandes OA. 2017. Diversity and abundance of edaphic arthropods associated with conventional and organic sugarcane crops in Brazil. Florida Entomol 100 (1): 134-144. DOI: $10.1653 / 024.100 .0119$

Saona CR, Blaauw BR, Isaacs R. 2011. Manipulation of natural enemies in agroecosystems: habitat and semiochemicals for sustainable insect pest control. In: Larramendy ML (ed.). Integrated Pest Management and Pest Control - Current and Future Tactics. IntechOpen, UK.

Simão FCP, Carretero MA, do Amaral MJA, Soares AMVdM, Mateos E. 2015. Composition and seasonal variation of epigeic arthropods in field margins of NW Portugal. Turk J Zool 39: 404-411. DOI: $10.3906 /$ zoo-1401-69.

Sommaggio D, Peretti, E, Burgio G. 2018. The effect of cover plants management on soil invertebrate fauna in vineyard in Northern Italy. Biocontrol 63: 795-806.DOI: 10.1007/s10526-018-09907-z.

Stefani V, Pires TL, Torezan-Silingardi HM, Del-Claro K, Ballhorn D. 2015. Beneficial effects of ants and spiders on the reproductive value of Eriotheca gracilipes (Malvaceae) in a Tropical Savanna. PLoS ONE 10 (7): e0131843. DOI: 10.1371/journal.pone.0131843.

Sulaiman AA, Sulaeman Y, Mustikasari N, Nursyamsi D, Syakir AM. 2019. Increasing sugar production in indonesia through land suitability analysis and sugar mill restructuring. Land J 61: 1-17. DOI: 10.3390/land8040061. 